COMMENT

DOI: $10.1057 /$ s41599-018-0092-x

\title{
Horror and the Gothic's utility as a cultural resource and critical tool
}

\author{
John Edgar Browning ${ }^{1}$
}

\begin{abstract}
While cultural theory elitists have tended to write off familiar monsters as little more than cheap fads of mass culture, popular culturists often embrace them as effective barometers capable of measuring and, at times, even predicting collective sentiments and anxieties. Yet frequently ignored in this disciplinary clash is the notion that monstrous figures also serve as excellent case studies for a much broader issue: the argument for Popular Culture Studies as a pertinent division of cultural theory. This article argues that popular culture can and does respond to public needs, that consumers do indeed show the capacity for resisting cultural indoctrination and can, at times, even directly influence it. Of this there are, perhaps, no better examples than the vampire and zombie, figures who in one form or another have served primarily as maleficent beings until 21st century culture transmuted them into heroes and harbingers of social change.
\end{abstract}

\footnotetext{
${ }^{1}$ Georgia Institute of Technology, Atlanta, GA, USA. Correspondence and requests for materials should be addressed to J.E.B. (email: john.browning@lmc.gatech.edu)
} 


\section{In defense of fear}

$\mathrm{M}$ onsters like the ever-popular vampire and zombie, figures who have served for centuries as maleficent beings in both folklore and popular fiction, have transformed in the 21st century into heroes and harbingers of social change. According to Nelson (2012) in Gothicka: Vampire Heroes, Human Gods, and the New Supernatural, this revolutionary new trend has, since September 11, 2001, "rehabilitat(ed) supernaturalism as an esthetic mode-brighter, more Romantic, and more culturally heterodox within the framework of postcolonial global popular culture" (pp 11-12). For Nelson, supernaturalism has wrenched itself from evil's exclusive domain and become normalized in daily life, producing in the process a brave, new world of monstrous Samaritans, a world in which vampires and zombies, for example, can become hero-gods and -goddesses, and where what was once repulsive can now be beautiful.

Yet, as I have tried to show elsewhere (Browning, 2015), vampires and zombies did not simply transform overnight as some recent scholarship has insinuated. Indeed, there appeared along the way various signs, tremors, and slow evolutionary markers. While September 11 almost certainly gave rise to the postmillennial turn of which Nelson and others have treated in an increasingly growing (and increasingly indispensable) body of scholarship, that fateful day was also, if merely, the "catastrophic and catalyzing event" (i.e., "like a new Pearl Harbor," to use Donald Rumsfeld and Paul Wolfowitz's statement to Project for the New American Century [2000]) that accelerated a much greater evolutionary process that had been going on for decades. What inevitably predicted this turn was, in short, popular culture -the everyday.

It is not uncommon for horror scholarship to invoke studies of the everyday and non-violent in American society, even when the benefit of doing so is difficult to recognize. On the contrary, these areas help precisely in illuminating critical, if otherwise unlikely connections between conceptually disparate categories. Indeed, because the normalcy of the everyday configures, in part, what we deem other, or out there, we can learn much when these boundaries are in flux. The popular television series Dog Whisperer with Cesar Millan (2004-2016) offers a prescient view of the current instability of these boundaries. The beginning of every episode records the host avowing how and why the show was founded, "I rehabilitate dogs; I train people," a reference to where Cesar Millan feels the blame for canine misbehavior must be laid. "When we humanize dogs," Millan explained to Moran (2014) in The Philippine Star, "we create an imbalance in their natural state... I hope that through understanding the world that dogs live in, people will transform their dogs-and maybe a bit of themselves at the same time." Much can be said about Millan's dog show vis-à-vis the general state of horror over the last two decades.

Filmmakers today are rehabilitating monstrous figures like vampires and zombies. Millan's sentiment, if we swap out "dog" for "monster," is therefore apt: "When we humanize [monsters]," which is to say figuratively cloth them in the prevailing sins or otherwise deviant markers $d u$ jour, "we create an imbalance in [our] natural state.... I hope that through understanding the world that [monsters] live in, people will transform their [monsters] - and maybe a bit of themselves at the same time." The revolutionary direction of this new, "postmillennial" Gothic is, again to return to Nelson (2012), "rehabilitating supernaturalism as an esthetic mode" (xi). In turn, what we see emerging from the twenty-first century's horror and Gothic subgenres is Nelson's (2012) aptly phrased "dark sublime's antithesis": beauty uniting the "Gothick and Romantic traditions as this hybrid sensibility continues to morph to meet the changing consciousness of our culture" (17). Still, monsters generally, and vampires and zombies particularly, continue to have to fight for their place at the (dinner) table.

On the one hand, figures like the zombie and vampire are written off by cultural theory elitists as nothing more than a cheap fad, a product of mass culture. On the other hand, however, they serve effectively as barometers in the hands of popular culturists at measuring, even predicting collective sentiments and cultural trends and anxieties. Yet frequently ignored is the fact that figures like the zombie and vampire also serve as excellent case studies for a much broader issue: the argument for Popular Culture Studies itself as a pertinent, illuminating division of cultural theory and a producer of knowledge.

\section{Raising brows with popular culture}

How can popular culture be seriously used as a way to look at American history and culture? Further still, can it go so far even as to interact with and reciprocally influence it? If so, what is the basis for this level of intertextuality? If not, is it in danger of becoming simply a system of superficial explanations-a sort of reflectionism of cultural moments? Popular Culture Studies has and continues to wrestle with this dilemma. Perhaps a better question is how do Zombie and Vampire Studies, as a case in point, help us to engage some of the broader issues within Popular Culture Studies about its productivity, applicability, and focus?

The battle for Popular Culture Studies's legitimacy as a real academic discipline has long been won, its credentials set in place. This is not in question. Rather, it is Popular Culture Studies's utility along other, more established and intellectually recognized disciplines that is the matter at hand. What I refer to simply as the "epistemological productivity" of other, similar disciplines generally encounters far less scrutiny from scholars, and this arguably has much (if not everything) to do with the nature of Popular Culture Studies's critical focus.

Popular Culture Studies is the scholarly inquiry of those customs, events, artefacts, myths, language, etc. which are shared by the masses. If someone attends a sporting event, watches television, watches or reads an advertisement, reads a mass-market book, retweets something online, or uses common gestures or idiomatic expressions to communicate with another person, then he or she is participating in popular culture. Popular Culture Studies examines these cultural features as well as their history over time, examining whether particular phenomena are at work. Thus, scholars of popular culture take quite seriously what others might offhand deem trivial, or generic. Indeed, it is the very genericalness of popular culture which prompts these scholars to believe it is more than just the selling and consuming of products: that popular culture is, in fact, capable of reflecting the values, opinions, feelings, and the patterns of thought generally understood and circulated by significant portions of the cultures or nations in which these values, opinions, feelings, and patterns occur.

Key to contemporary Popular Culture Studies is, I would argue, its use of critical lenses that can re-evaluate almost anything, a process that probably has its roots in the discipline's originary need to explain why something so popular and pervasive in society can actually hold real meaning. Rossatto et al. (2006) anthology Reinventing Critical Pedagogy: Widening the Circle of Anti-Oppression Education (2006) comments upon this importance. The process of questions leading to responses, leading to open dialogs, leading to further inquiry, generates in cultural circles what may be called "dialectic flows," which, according to Lea (2006), "guide the process of decoding the codification" (211). Why is this important with popular cultural artefacts? Because 
many of such artefacts control and oppress as much as they provide pleasure. Kellner (2011) explains, succinctly, that:

Radio, television, film, and the other products of media culture provide materials out of which we forge our very identities; our sense of selfhood; our notion of what it means to be male or female; our sense of class, of ethnicity and race, of nationality, of sexuality; and of "us" and "them." Media images help shape our view of the world and our deepest values: what we consider good or bad, positive or negative, moral or evil.... Media spectacles demonstrate who has power and who is powerless, who is allowed to exercise force and violence, and who is not. They dramatize and legitimate the power of the forces that be and show the powerless that they must stay in their places or be oppressed. (p 7; italics are the author's)

Kellner is apt to point out that the inherently evaluatory lens through which we study media and popular culture is crossdisciplinary, designed in its use to accommodate Class Studies, Gender Studies, and Sexuality Studies, as well as meet the needs of feminists and queer theorists. Thus, Popular Culture Studies equips not only its own students, but students in other, related disciplines who appropriate its theoretical tool belt, with the critical know-how to analyze, from a variety of disciplinary perspectives, a range of cultural productions and practices that they confront on a day to day basis. These students begin the process of making connections between everyday popular events and products, becoming informed consumers in and engaged participants of a global community in which cultural industries centrally shape politics and economics.

Things are not always so pessimistic though, and Popular Culture Studies does not always have to be a shield; sometimes, it finds that everyday people are fighting back against oppression and hierarchical power structures. Contemporary studies of popular culture, free of the previously held and widely accepted view that all popular cultural products, needs, and ideas are dictated by consumer capitalism and intended upon controlling and subordinating the masses, now concede that popular culture can and does respond to public needs, that consumers do indeed show the capacity for resisting cultural indoctrination and can even, at times, directly influence it. No truer is this than in particularly terrifying, or titillating, mass forms like the zombie and vampire.

Learning from the dead. The fields of Zombie and Vampire Studies are well suited to case study the discourse about Popular Culture Studies's epistemological productivity vis-à-vis other culturally-based scholarly disciplines. Even though Zombie and Vampire Studies are still in their relative infancy, they have produced, in particular in the last 10 years, a range of scholarship that achieves much of the same critical aims as their parent discipline of Popular Culture Studies, albeit in a more targeted way. This, to me, proves most strikingly of all that zombies and vampires can share such a genealogically similar history and yet produce such widely thematically variant interpretative scholarship. HBO's hit television series True Blood was probably the best thing to happen to vampires since the 1990s, a decade which gave us the immensely popular Bram Stoker's Dracula (1992) and Interview with the Vampire (1994). True Blood, as with the latter film titles, is the culmination of a century of politico-sexual tensions and re-negotiation in vampire cinema. As I explained previously during an interview (Humphreys, 2014), the folklore or mythos used to tell the story of True Blood's vampires is considerably less important, I found, than how the vampires themselves actually behaved during the show. I would go on to explain:

What (or whom) they do with their fangs, and whether or not they are afterwards punished for it, has long been important in the cinema, just as it was to the European villagers of centuries ago who actually believed in vampires. Vampires today (save perhaps for the Twilight movies) are free to be. This is not to say contemporary vampires are gayer; it just matters less to us where they are sticking their fangs. Vampires, simply and plainly put, are us. How we regulate them is how we regulate ourselves. (pp 110-111)

If we turn to zombie films, however, considerably more important is how the survivors (or victims) themselves behave, especially while confined together in what I call the "survival space" (Browning, 2016), a socially and politically turbulent "public performance space" "whose occupants must, together, fortify (and defend) in order to protect the enclosure from what is 'outside"' (13). Mass products like zombies and vampires facilitate the active role of Popular Culture Studies as a powerful theoretical lens. Indeed, in light of monstrous figures since September 11, perhaps we will see this power-play in action once more amid the current political climate in the US, in turn underscoring the potential for monstrosity in affecting-and effecting-current representational forms.

A stirring debate today in universities continues to be the distinction between "high" art and "low" art (or popular culture). However, scholars are finding such a distinction more and more arbitrary, perhaps because the boundary separating high and low art has begun to blur, blend, or in some places dissolve all together. Invariably what constitutes popular culture can be hard to define, but why popular culture matters isn't such a difficult question. Popular culture is commonly associated with what is readily accessible or mass produced. Theorists outside the discipline of Popular Culture Studies tend to question the value of culture intended for mass consumption and designed, ultimately, for commercial gain. Yet, theorists in Popular Culture Studies, myself included, contend that is precisely the reason for exploring popular culture and why doing so is crucial: because it can and does exude such great influence on identity-making and a society's ability not only to access but produce knowledge. Thus, as I hoped to show in my cursory examination of the vampire and zombie-or as the more expansive articles in this journal's article collection on Studies in horror and the Gothic $(2017)^{1}$ elucidate in a myriad of thematic areas-critical analyses of popular cultural production are imperative for understanding not only ourselves and where we have been, but also where we are going. Sometimes the future our wild work sees is bright, sometimes dark, but which one is almost never clear, at least, not until it is too late. And that, perhaps, is the real horror.

Received: 6 February 2018 Accepted: 12 March 2018

Published online: 10 April 2018

\section{Notes}

1 Studies in horror and the Gothic (article collection) (2017) Palgrave Communications. https://www.nature.com/collections/nsfrsncwwy.

\section{References}

Browning JE (2015) Redeeming the un-dead in American media and culture before 9/11, Ph.D. thesis, State University of New York at Buffalo

Browning JE (2016) Survival horrors, survival spaces: tracing the modern zombie (cine)myth through to the postmillennium. In: Castillo DR, Schmid D, Reilly 
DA, Browning JE (eds) Zombie talk: culture, history, politics. Palgrave Macmillan, New York, pp 9-38

Browning JE (2017) Studies in horror and the Gothic [Article Collection]. Palgrave Communications

Dog Whisperer with Cesar Millan (2004-2016). National Geographic Channel, Nat Geo Wild. (Television program)

Humphreys J (2014) Interviews too shocking to print!: conversations with horror filmmakers and their accomplices. BearManor Media, Albany

Kellner D (2011) Cultural studies, multiculturalism, and media culture. In: Dines G, Humez JM (eds) Gender, race, and class in media: a critical reader, 3rd edn. SAGE, Los Angeles, pp 7-18

Lea Y (2006) The matrix of Freirean pedagogy: time and cultural literacies. In: Rossatto CA, Allen RL, Pruyn M (eds) Reinventing critical pedagogy: widening the circle of anti-oppression education. Rowman \& Littlefield Publishers, Lanham, pp 207-224

Moran K (2014) Cesar Millan whispers: 'It is easier to train dogs than people'. May 4 The Philippine Star, https://www.philstar.com/lifestyle/pet-life/2014/05/04/ 1318949/cesar-millan-whispers-it-easier-train-dogs-people

Nelson V (2012) Gothicka: Vampire Heroes, Human Gods, and the New Supernatural. Harvard University Press, Cambridge

Project for the New American Century (2000) Rebuilding America's Defenses: Strategy, Forces and Resources for a New Century. The Project for the New American Century, Washington

Rossatto CA, Allen RL, Pruyn M (eds) (2006) Reinventing critical pedagogy: widening the circle of anti-oppression education. Rowman \& Littlefield Publishers, Lanham

\section{Additional information}

Competing interests: The author declares no competing interests.

Reprints and permission information is available online at http://www.nature.com/ reprints

Publisher's note: Springer Nature remains neutral with regard to jurisdictional claims in published maps and institutional affiliations.

(c) (i) Open Access This article is licensed under a Creative Commons Attribution 4.0 International License, which permits use, sharing, adaptation, distribution and reproduction in any medium or format, as long as you give appropriate credit to the original author(s) and the source, provide a link to the Creative Commons license, and indicate if changes were made. The images or other third party material in this article are included in the article's Creative Commons license, unless indicated otherwise in a credit line to the material. If material is not included in the article's Creative Commons license and your intended use is not permitted by statutory regulation or exceeds the permitted use, you will need to obtain permission directly from the copyright holder. To view a copy of this license, visit http://creativecommons.org/ licenses/by/4.0/.

(C) The Author(s) 2018 